\title{
DROSERA FILIFORMIS RAF. FORMA VIRIDIS J.KSEPKA F. NOV
}

JASON KSEPKA • Farmingdale • New Jersey •USA • jasonksepka@gmail.com

Submitted: 28 February 2020.

Abstract: Drosera filiformis Raf. f. virdis J.Ksepka, an anthocyanin-free variant of Drosera filiformis from New Jersey, USA, is described.

DIAGNOSIS: All parts of this plant are devoid of red pigmentation. Leaves are green, flowers are pure white. In all other respects this form is identical in habit, characteristics and habitat to the typical form of Drosera filiformis.

TYPE: Ocean County, New Jersey, USA. June 1, 2014, J.Ksepka, s.n. deposited in Academy of Natural Sciences Herbarium, Philadelphia, Pennsylvania (PH, holotype).

On June 1, 2014, I discovered a clump of anthocyanin-free Drosera filiformis in Ocean County, New Jersey. I was traveling along a route that I have taken many times previously when something caught my eye. It was late in the day and the sunlight was peeking through the branches of an Atlantic white cedar. Where the light fell on the ground, the sundews lit up and glowed. This light show is a familiar and welcomed sight. But something struck me as different this time. The usual pink color cast was not there, these plants were "glowing" green. I immediately went to investigate and found a small clump of about a dozen crowns of Drosera filiformis that had no red pigment at all. I
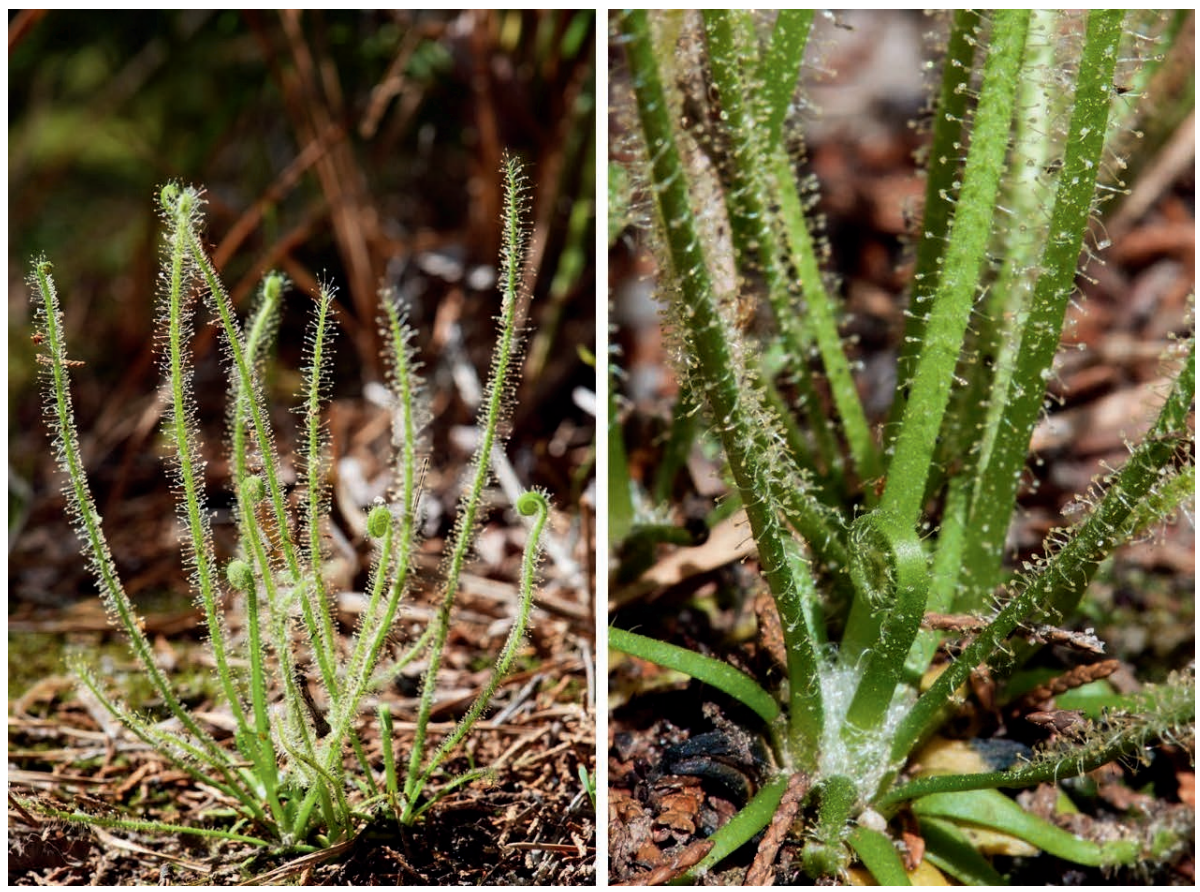

Figure 1: Drosera filiformis f. viridis as found in situ on June 1, 2014 in Ocean County, New Jersey (left); close-up of plants at time of discovery (right). 

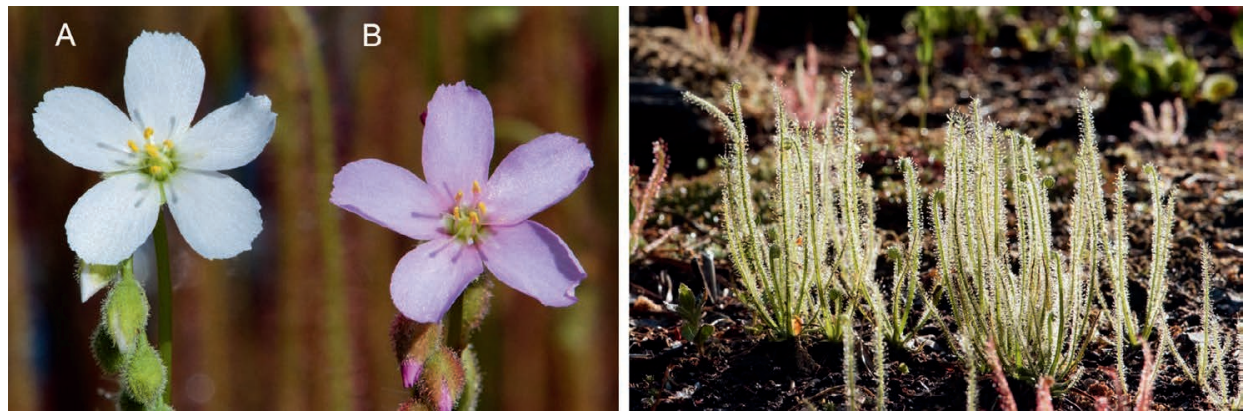

Figure 2: Flower of Drosera filiformis f. viridis (A) and Drosera filiformis typical (B). Both examples are cultivated plants from New Jersey stock (left); Drosera filiformis f. viridis growing in the author's bog garden in May 2017 (right).

was ecstatic to see something that I had hoped for years I would see. Finally, the anthocyanin-free form of Drosera filiformis!

I collected four of the plants, and left the remaining plants as they were. In general, I do not collect, nor condone the collection of wild plants. But the nature of this rarity, and the fact that the clump was in a somewhat hazardous location prompted me to do so. I also am in good standing with the managers of this property and have permission. Collecting should never be done without permission, and always done ethically. That being said, I am glad that I collected them.

The next year, I returned to visit this location and indeed all of the plants were gone except for a tiny seedling or division. The following year, this plant was gone as well. Someone else may have removed them, but the clump was situated on the edge of a trail frequently travelled by fishermen. Additionally, it was adjacent to a heavily eroded sand road with water regularly washing down and eroding the trail where the plants were. I still check the site, and downstream to see if there are any other anthocyanin-free plants, but have not relocated any.

I have been propagating these plants to increase the number and make them available to other hobbyists. I have had some setbacks. The first year of seed propagation was lost to one or more curious squirrels. The second year was lost to a drought and my absence conducting field work. The third year saw low germination due to insufficient stratification. I stratified the seed for 2 months, but had about $10 \%$ germination rate. I did however hedge my bets this time and a fair number of leaf cuttings are doing well. The fourth year (2019), I will properly stratify the seed from 2018, as well as more leaf cuttings to finally get a good bump in production.

Despite the unfortunate setbacks that I have had, this form is easily reproduced from seed or vegetative means and comes true to form. The anthocyanin-free trait is a well-known single-allele recessive trait that produces a plant incapable of having any red coloration in any part of the plant. These plants are a very crisp green color with clear tentacles and glands, and pure white flowers. Compared to the typical green leaves with various amounts of red in the tissue, and clear to red tentacles, red glands, and pink or red flowers. Drosera filiformis f. viridis is named due to the pure green and complete lack of any red color, rather than "f. alba" often used for such plants, as this name refers to the white flower, which is only one character of an anthocyanin-free plant.

In all other respects of characteristics and culture, Drosera filiformis f. viridis is identical to typical Drosera filiformis. Because this genetic trait is well understood, stable, easily reproduced, and can randomly be expressed at any point in a population, any Drosera filiformis fitting this description should be referred to as Drosera filiformis f. viridis. 